\title{
THE
}

\section{Habitat Selection and Home Range Size of Ruffed Grouse in Rhode Island}

\author{
Erik G. Endrulart \\ University of Rhode Island \\ Scott R. McWilliams \\ University of Rhode Island \\ Brian C. Tefft
}

Follow this and additional works at: https://digitalcommons.uri.edu/nrs_facpubs

Terms of Use

All rights reserved under copyright.

\section{Citation/Publisher Attribution}

Endrulat, E. G., McWilliams, S. R., \& Tefft, B. C. (2005). Habitat Selection and Home Range Size of Ruffed Grouse in Rhode Island. Northeastern Naturalist, 12(4), 411-424. doi: 10.1656/ 1092-6194(2005)012[0411:HSAHRS]2.0.CO;2 Available at: https://doi.org/10.1656/1092-6194(2005)012[0411:HSAHRS]2.0.CO;2

This Article is brought to you for free and open access by the Natural Resources Science at DigitalCommons@URI. It has been accepted for inclusion in Natural Resources Science Faculty Publications by an authorized administrator of DigitalCommons@URI. For more information, please contact digitalcommons-group@uri.edu. 


\section{BioOne enesenen}

\section{Habitat Selection and Home Range Size of Ruffed Grouse in Rhode Island}

Author(s): Erik G. Endrulat, Scott R. McWilliams, Brian C. Tefft

Source: Northeastern Naturalist, 12(4):411-424.

Published By: Eagle Hill Institute

https://doi.org/10.1656/1092-6194(2005)012[0411:HSAHRS]2.0.CO;2

URL: http://www.bioone.org/doi/

full/10.1656/1092-6194\%282005\%29012\%5B0411\%3AHSAHRS

\%5D2.0.CO\%3B2

BioOne (www.bioone.org) is a nonprofit, online aggregation of core research in the biological, ecological, and environmental sciences. BioOne provides a sustainable online platform for over 170 journals and books published by nonprofit societies, associations, museums, institutions, and presses.

Your use of this PDF, the BioOne Web site, and all posted and associated content indicates your acceptance of BioOne's Terms of Use, available at www.bioone.org/page/terms of use.

Usage of BioOne content is strictly limited to personal, educational, and noncommercial use. Commercial inquiries or rights and permissions requests should be directed to the individual publisher as copyright holder. 


\title{
Habitat Selection and Home Range Size of Ruffed Grouse in Rhode Island
}

\author{
Erik G. Endrulat ${ }^{1,3, *}$, Scott R. McWilliams ${ }^{1}$, and Brian C. Teffi ${ }^{2}$
}

\begin{abstract}
Bonasa umbellus (Ruffed Grouse) are one of many wildlife species that require early successional forest and whose populations have declined as New England forests have matured. We studied habitat selection and home range size of Ruffed Grouse in oak-hickory forests in Rhode Island to determine the importance of different habitat types for grouse. Home range size did not significantly differ by age or gender $($ mean $=103 \pm 24.91$ ha). Habitat selection was assessed at two spatial scales: home range and study area scale. At the study area scale, grouse selected early successional forest, mixed deciduous-conifer stands, deciduous forest, and forested roads, whereas grouse avoided evergreen forests and developed areas. Given that grouse selected early successional forests at a relatively large spatial scale, we suggest that the conservation and restoration of early successional forested habitats will benefit Ruffed Grouse and many other associated wildlife.
\end{abstract}

\section{Introduction}

Bonasa umbellus (Linnaeus) (Ruffed Grouse) are one of many wildlife species whose populations are declining as New England forests mature (Dessecker and McAuley 2001). Grouse require early successional forest with high stem densities for cover and openings that provide grasses and herbaceous vegetation for foraging (Bump et al. 1947, Lorimer 2001, Whitaker 2003). Scolopax minor Gmelin (American Woodcock) are also associated with dense, early successional forests, and their populations are declining along with those of Ruffed Grouse (Dessecker and McAuley 2001). Many migratory songbirds that use disturbance-dependent habitats (e.g., Dendroica pensylvanica (Linnaeus) [Chestnut-sided Warblers], Vermivora chrysoptera (Linnaeus) [Golden-winged Warblers], and Dendroica cerulea (Wilson) [Cerulean Warblers]) are the focus of recent conservation efforts because of their declining populations (Askins 2000, Hunter et al. 2001). Mammals that specialize on early successional forest habitats (e.g., Sylvilagus transitionalis (Bangs) [New England cottontails]), and predators of early successional species (e.g. Lynx rufus (Schreber) [bobcats]), are also species declining in the eastern United States as forests mature and become increasingly fragmented (Litvaitis 1993, 2001; Litvaitis et al. 1986). Thus, conservation of early successional forested communities would likely benefit Ruffed Grouse as

\footnotetext{
${ }^{1}$ Department of Natural Resources Science, University of Rhode Island, Coastal Institute in Kingston, Kingston, RI 02881. ${ }^{2}$ Division of Fish and Wildlife, Rhode Island Department of Environmental Management, PO Box 218, West Kingston, RI 02892. ${ }^{3}$ Current address - Rhode Island Natural History Survey, Room 101, Coastal Institute in Kingston, 1 Greenhouse Road, University of Rhode Island, Kingston, RI 02881-0804. "Corresponding author - eendrulat@ rinhs.org.
} 
well as a diversity of associated wildlife, including both game and non-game species (Thompson and DeGraaf 2001).

Similar to forests throughout the eastern United States, forests in Rhode Island are maturing and are subject to little natural disturbance (e.g., fires) or timber harvesting (Butler and Wharton 2002, Trani et al. 2001). For example, Rhode Island forests were on-average 40 years old in 1985 compared to 60 years old in 1998 (Butler and Wharton 2002), with only 8000 ha (6\%) of the forest in a seedling-sapling age class by 1998 (Trani et al. 2001). Forest inventories also indicate that as forests shift to Acer-Betula (maplebirch) and Quercus-Pinus (oak-pine) forests, the area of Quercus-Carya (oak-hickory) forests in the state is declining (Butler and Wharton 2002). Reasons for these shifts include Lymantria dispar L. (gypsy moth) infestations in the 1980s and past use of high-grade silviculture practices (Butler and Wharton 2002).

Increasing human populations in Rhode Island over the past half-century have diminished forest area and caused increased forest fragmentation (Butler and Wharton 2002). Coincident with these changes in forest habitats, hunter surveys collected by the Rhode Island Division of Fish and Wildlife over the past 50 years have suggested that Ruffed Grouse harvest rates in Rhode Island have declined (Tefft 1999) (Fig. 1).

Our study evaluates the importance of different habitat types, particularly early successional forests, for Ruffed Grouse in mature oak-hickory forests in Rhode Island. Habitat selection and home range size of grouse has not been previously studied in Rhode Island, although a better understanding

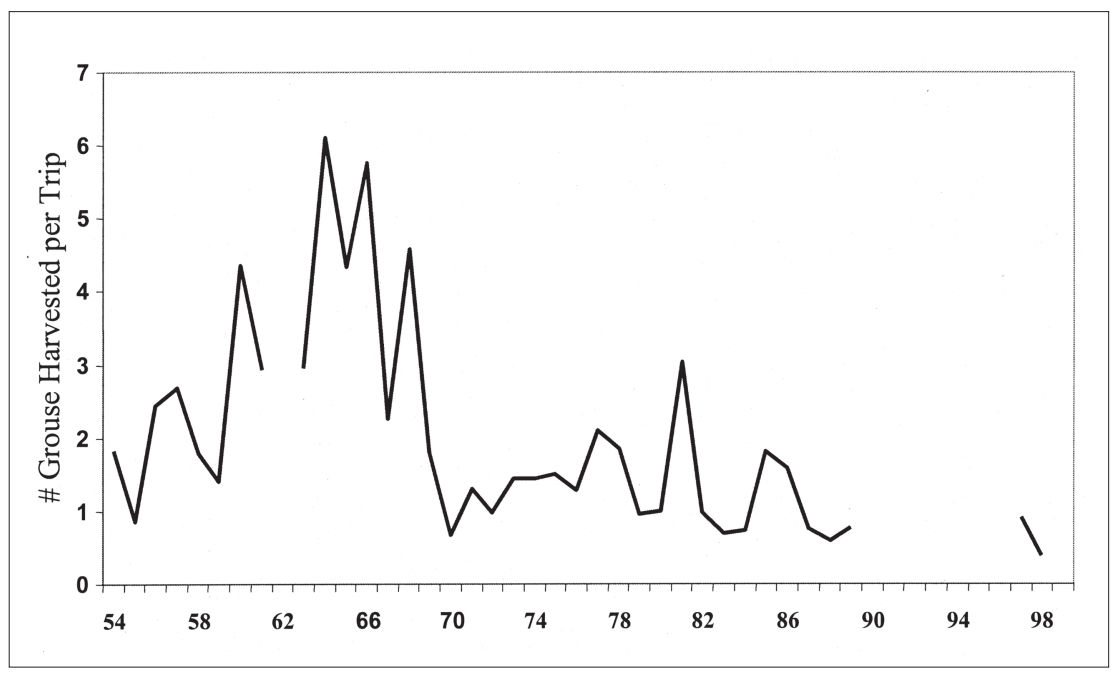

Figure 1. Index of Ruffed Grouse abundance in Rhode Island, 1954-1999. Data were from Rhode Island Fish and Wildlife mail-in hunting harvest surveys in which hunters reported the number of grouse harvested per trip. Data represents a survey of hunter reports over 173,225 hours and 51,205 individual trips. No data were available for 1962 or 1989-1996. 
of habitats selected by grouse will improve management for Ruffed Grouse and other early successional wildlife. As part of the Appalachian Cooperative Grouse Research Project (ACGRP), we conducted a three-year study of grouse in Rhode Island with two main objectives: 1) to calculate home range size of grouse in Rhode Island and test for age or gender differences, and 2) to assess habitat selection of grouse in primarily oak-hickory forests in western Rhode Island. The Appalachian Cooperative Grouse Research Project investigated Ruffed Grouse population dynamics and hunting impacts at 12 study sites in 8 states in the Appalachians over 6 years.

\section{Study Area}

The study site is 6621 ha and is located in Washington County, RI $\left(41^{\circ} 32^{\prime} \mathrm{N}, 71^{\circ} 43^{\prime} \mathrm{W}\right)$. Approximately $55 \%$ (3685 ha) of the area is the statewned Arcadia Wildlife Management Area (AWMA); the remaining 45\% (2963 ha) is privately owned. The study area is near the southern boundary of the glaciated section of the oak-chestnut region (Braun 1950). Topography of this area is typical of the Seaboard Lowland subprovince of the New England physiographic province (Fenneman 1938) with elevation rises generally less than $50 \mathrm{~m}$. Forests are mostly second growth, even-aged stands generated from sprouts following sporadic clearcutting during the early 1900s (Braun 1950). The majority of the study area was formerly oak-chestnut forest until the chestnut blight of the early 1900s. Contemporary forests are dominated by Quercus alba L. (white oak) and Q. rubra L. (red oak) (Braun 1950). Pinus rigida Miller (pitch pine), red oak, and Q. ilicifolia Wangenh. (scrub oak) are common on dry, sandy locations, whereas Acer rubrum L. (red maple), white oak, and Nyssa sylvatica Marsh. (black gum) are more common on poorly drained soils. A dense and low-growing ericaceous layer composed mainly of Kalmia latifolia L. (mountain laurel), Gaylussacia baccata (Wangenh.) K. Koch (black huckleberry), Vaccinium spp. (high and lowbush blueberries), and Rhododendron viscosum (L.) Torr (swamp azalea) is common throughout this area (Braun 1950).

Forest management in the AWMA is currently limited to maintenance of wildlife food plots (131 ha), small clearcuts (<10 ha), and brush cutting to preserve road edges. There are several reverting agricultural fields (25 ha), some of which are mowed annually or biennially to minimize woody plant growth.

\section{Methods}

\section{Data collection}

Trapping. We used clover-leaf traps to capture grouse (Gullion 1965) during the fall and spring trapping periods of 1999-2002. Traps were placed close to roads and in habitats deemed suitable to support grouse. Captured birds were weighed, age was determined by examination of primary molt wear, and gender was determined by length of the central tail feather and by 
examination of rump feathers (Davis 1969). We fitted birds with 11-12-g necklace-type radio transmitters operating in the $150-151 \mathrm{MHz}$ frequency range (Advanced Telemetry Systems, Isanti, MN). Transmitters had mortality sensors and a life expectancy of approximately one year. Birds were also given a uniquely numbered aluminum leg band for identification. These methods were the standard protocol used for trapping and determining age and gender of Ruffed Grouse for all studies involved in the ACGRP and were approved by the University of Rhode Island Institutional Animal Care and Use Committee (IACUC Protocol No: AN00-09-009).

Radio telemetry. We collected telemetry locations diurnally, two to three times per week, with hand-held radio receivers and three-element Yagi antennas (Advanced Telemetry Systems, Isanti, MN). We estimated grouse locations using at least three bearings taken within a 30-minute interval from separate telemetry stations. The UTM coordinates of each station were obtained using a global positioning system (GPS) differentially corrected against a base station. Whitaker (2003) found a consistent 5:1 ratio between geometric mean distance (GMD) error (i.e., the mean distance between telemetry stations and estimated location) and linear error. Therefore, for a given location with a $100 \mathrm{GMD}$, the estimated error ellipse of a circle with a $100-\mathrm{m}$ radius is equal to 1.01 ha. Of the 1659 locations originally collected, $27 \%(n=449)$ of locations were removed because they had > 800-m GMD or $>10$-ha error ellipse.

Stand data. Land-use and roads data from Rhode Island Geographical Information Systems (RIGIS; www.edc.uri.edu/rigis) were included in a geographic information system (GIS) for the Rhode Island study site. Stand data for the Rhode Island study site included nine land-use categories (Table 1). Abandoned fields and recent clearcuts that were not included in

Table 1. Description of land-use types and their absolute (ha) and relative area (\%) on a Rhode Island study site where Ruffed Grouse home range and habitat selection were studied during 1999-2002.

\begin{tabular}{|c|c|c|c|c|}
\hline Land-use type & Acronym & Description & Area (ha) & $\begin{array}{l}\text { Relative } \\
\text { area }(\%)\end{array}$ \\
\hline Deciduous forest & Decid & $>80 \%$ deciduous trees & 2420 & 38 \\
\hline Evergreen forest & Evg & $>80 \%$ evergreen trees & 654 & 10 \\
\hline Mixed forest & Mix & $\begin{array}{l}>20 \% \text { deciduous } \\
>20 \% \text { evergreen tree mix }\end{array}$ & 1689 & 26 \\
\hline $\begin{array}{l}\text { Early successional } \\
\text { forest }\end{array}$ & ESH & $\begin{array}{l}\text { Shrub-brushland, clearcuts, } \\
\text { reverting farmland }\end{array}$ & 125 & 2 \\
\hline Agriculture & $\mathrm{Ag}$ & Pasture, cropland, orchards & 230 & 4 \\
\hline Wetlands & Wet & $\begin{array}{l}\text { Forested and non-forested } \\
\text { wetlands }\end{array}$ & 631 & 10 \\
\hline Developed & Dev & Urban or built-up land & 289 & 5 \\
\hline Roads & $\mathrm{Rd}$ & $\begin{array}{l}15-\mathrm{m} \text { buffer surrounding } \\
\text { roads }\end{array}$ & 267 & 4 \\
\hline Water & Wat & Reservoirs, lakes, ponds & 81 & 1 \\
\hline Total & & & 6414 & 100 \\
\hline
\end{tabular}


the original RIGIS land use data were digitized at a scale of 1:3000 in ArcView (ESRI 1994).

Berner and Gysel (1969) suggested that access roads and logging trails may be preferentially used by grouse. We identified road corridors as a separate habitat category in the analysis. The road habitat category was defined as $7.5 \mathrm{~m}$ on both sides of the road's center, so that the road habitat category included the roads plus the roadside habitat that is typically maintained by mowing and brush clearing.

\section{Statistical analyses}

Home range estimation. The Animal Movements extension in ArcView 3.2 was used to calculate home ranges for each bird (ESRI 1994, Hooge et al. 1999). Fixed kernel estimation with least squares cross validation smoothing (Worton 1989) and minimum convex polygons (MCPs) (Mohr 1947) were used to estimate the home ranges of all grouse with at least 25 locations over the duration of the study (Seaman et al. 1999). We used a Pearson product moment correlation to test for a correlation between number of days a grouse was tracked and estimated home-range size of grouse (SPSS 1999). After finding no significant difference between home-range size of grouse with $\leq 365$-d and those with $>365$-d, we decided to include $>365$-d of telemetry data in home-range estimates. The kernel technique was chosen because it is the least biased home-range estimator available (Seaman and Powell 1996, Seaman et al. 1999). We also report estimates of grouse home range using the MCP method for comparison with other studies, although it is very sensitive to the number of radiolocations used (Jennrich and Turner 1969).

We tested for differences in the 95\%-isopleth kernel home-range size by age and gender using a univariate general linear model (GLM; SPSS 1999). Data were tested for normality with the Kolmogorov-Smirnov test and for equal variance with the Levene test (SPSS 1999). Data that did not meet the assumptions of the GLM were logarithmically transformed (base 10). Home-range values are presented as non-transformed mean area (ha) $\pm \mathrm{SE}$.

Habitat selection. Compositional analysis (Aebischer et al. 1993) was used to assess habitat selection in relation to stand type. The program BYCOMP (Ott and Hovey 2002) was used to perform compositional analysis in the SAS environment (SAS Institute 1989). Compositional analysis is preferred over other habitat selection analyses because it overcomes the unit-sum constraint common to many other methods (e.g., Neu et al. 1974), and it allows analysis of age and gender effects (Aebischer et al. 1993).

Habitat selection of grouse was evaluated at two spatial scales to account for hierarchical differences in the selection process (Johnson 1980), and because the boundaries that define available habitats are usually arbitrary (Johnson 1980, Porter and Church 1987). Selection was assessed at both the study-area (Johnson's second-order selection) and the home-range (Johnson's third-order selection) scale. The study-area boundary was defined as a polygon enclosing the outermost radio telemetry locations of the 
entire telemetry dataset. Available habitats in the study area were compared with those in the 95\%-isopleth kernel home range of each grouse at the study-area scale.

At the home-range scale, available habitat was defined as the composition of each bird's MCP home-range estimate. The MCP method provides a good estimate of the total area available to each bird because the boundaries are defined by the outermost locations at which each bird was found. Used habitat was defined as the $50 \%$-isopleth kernel home-range estimate (i.e., the core home range). Composition of stands by age class in the study area and in each grouse's home range was calculated using ArcInfo (ESRI 1994).

When habitat use was equal to zero for a given habitat category, we replaced zeros in the use category with a number less than the smallest nonzero value in the dataset (i.e., 0.001) (Aebischer et al. 1993). If a specific habitat was unavailable to most individuals, then that habitat type was removed from the analysis. At the home-range level, individual grouse who did not have one of the remaining habitats available to them were excluded from the analysis (i.e., after excluding habitats avoided by most birds at the study area level). The Kolmogorov-Smirnov test was used to assess the data for normality, and the assumption of equal variance was checked with the Levene test (SPSS 1999). Multicollinearity of the set of dependent variables was evaluated by performing correlation analysis with the full set of logratio differences.

\section{Results}

\section{Grouse home range size}

We collected locations for 26 grouse during an average of 356 days (range $=111-1,042, \mathrm{SE}=37.9)$ per bird. The number of days a grouse was tracked was not significantly correlated to the estimated home-range size $(r$ $=-0.126, \mathrm{P}=0.539)$. Home range for each grouse was estimated using on average 59 radiolocations (range $=25-205, \mathrm{SE}=8.0$ ). Mean home-range size of grouse was 104 ha $( \pm 24.9)$ based on the $95 \%$ kernel, 19 ha $( \pm 5.1)$ based on the $50 \%$ kernel, and 139 ha $( \pm 28.3)$ based on the MCP (Table 2). Kernel home-range size estimated using the $95 \%$ isopleths was similar for female $($ mean $=109 \pm 38.2 \mathrm{ha})$ and male grouse $\left(\right.$ mean $=102 \pm 31.6 \mathrm{ha} ; F_{1,22}$ $=0.765, \mathrm{P}=0.391)$. Area of the $95 \%$-isopleths home range was also similar

Table 2. Home range size of Ruffed Grouse based on 95\%- and 50\%-isopleth adaptive kernel and minimum convex polygon (MCP) methods, and number of Ruffed Grouse used to estimate home-range size on a study site in Washington County, RI, during 1999-2002.

\begin{tabular}{lrrcc} 
& \multicolumn{3}{c}{ Adaptive kernel } & \\
\cline { 3 - 4 } Gender or age & $\mathrm{n}$ & $95 \%$ isopleth & $50 \%$ isopleth & MCP \\
\hline Females & 7 & $109 \pm 38.2$ & $21 \pm 9.4$ & $183 \pm 74.8$ \\
Males & 19 & $102 \pm 31.6$ & $18 \pm 6.1$ & $122 \pm 28.0$ \\
Juvenile & 10 & $95 \pm 28.5$ & $21 \pm 6.8$ & $176 \pm 62.8$ \\
Adults & 16 & $110 \pm 37.0$ & $18 \pm 7.2$ & $116 \pm 24.6$ \\
Pooled & 26 & $104 \pm 24.9$ & $19 \pm 5.1$ & $139 \pm 28.3$ \\
\hline
\end{tabular}


for adult (mean $=110 \pm 37.0 \mathrm{ha})$ and juvenile grouse $($ mean $=95 \pm 28.5$ ha; age effect: $F_{1,22}=0.570, \mathrm{P}=0.458$; age by gender interaction: $F_{1,22}=1.226$, $\mathrm{P}=0.280$ ). Home ranges estimated using $\mathrm{MCP}$ were always larger than home ranges estimated using kernel isopleths, especially for female grouse $($ mean $=183 \pm 74.8$ ha; Table 2$)$.

\section{Habitat selection by grouse}

Grouse primarily used mixed deciduous-conifer and deciduous forest (36\% and $31 \%$ respectively for used habitat; Fig. 2 ). At the study-area scale, habitat use was significantly different than habitat availability $(\Lambda=0.223, \mathrm{P}$ $<0.05$ ), and grouse selected early successional habitat, mixed forest, and roads. They avoided developed land and coniferous habitats (Fig. 2a). At the home-range scale, grouse used habitats in proportion to their availability $(\Lambda$ $=0.859, \mathrm{P}=0.69)$ and so were nonselective in their habitat use (Fig. 2b).

\section{Discussion}

\section{Grouse home range size}

To our knowledge, this is the first published estimate of home-range size of Ruffed Grouse in southern New England. Mean home-range size of grouse in Rhode Island (mean $=104 \pm 24.9$ ha for 95\% kernels) was larger than reported in other localities. For example, annual home range of grouse in Virginia was $33 \pm 4.4$ ha (adaptive kernel) and $38 \pm 4.3$ ha (MCP; Fearer et al. 1999). Home range of adult male grouse in Tennessee was 37 ha (Boyd 1990). Home-range size of grouse in the Great Lakes region (Godfrey 1975, Maxson 1974) was also smaller than home range of grouse in Rhode Island. In contrast, 95\%-MCP home range of grouse in North Carolina (range $=43-92$ ha; Schumacher 2002) was similar in size to home range of grouse in Rhode Island. Whitaker (2003) found home ranges of females and juvenile males were $2 \mathrm{x}$ as large as adult males, summarizing data from 647 fall-winter and 407 spring-summer home ranges across 10 ACGRP study sites. Contrary to Whitaker (2003), we did not find significant differences in home-range size by age or gender, presumably due to insufficient sample size.

Home-range size of grouse in Rhode Island may be larger than in other areas because: 1) home ranges of Rhode Island grouse were estimated using locations combined across seasons, 2) resources in Rhode Island may be more dispersed across the landscape, or 3) resources in Rhode Island are of lower quality. Burt (1943:351) defined the home range of an animal as "that area traversed by the individual in its normal activities of food gathering, mating, and caring for young." We estimated home range of grouse using 25-205 locations collected during 111-1042 days, which is longer than most other studies of Ruffed Grouse home range. Ruffed Grouse in Rhode Island often occupied different areas during different seasons, which increased the size of the estimated home range. In Virginia, Fearer et al. (1999) also reported larger home ranges of grouse when estimated annually compared to seasonally. 
Large home-range size may occur because resources available to grouse are widely dispersed across the landscape (McNab 1963, Thompson and Fritzell 1989). In high quality habitats, grouse may use a small area (i.e.,

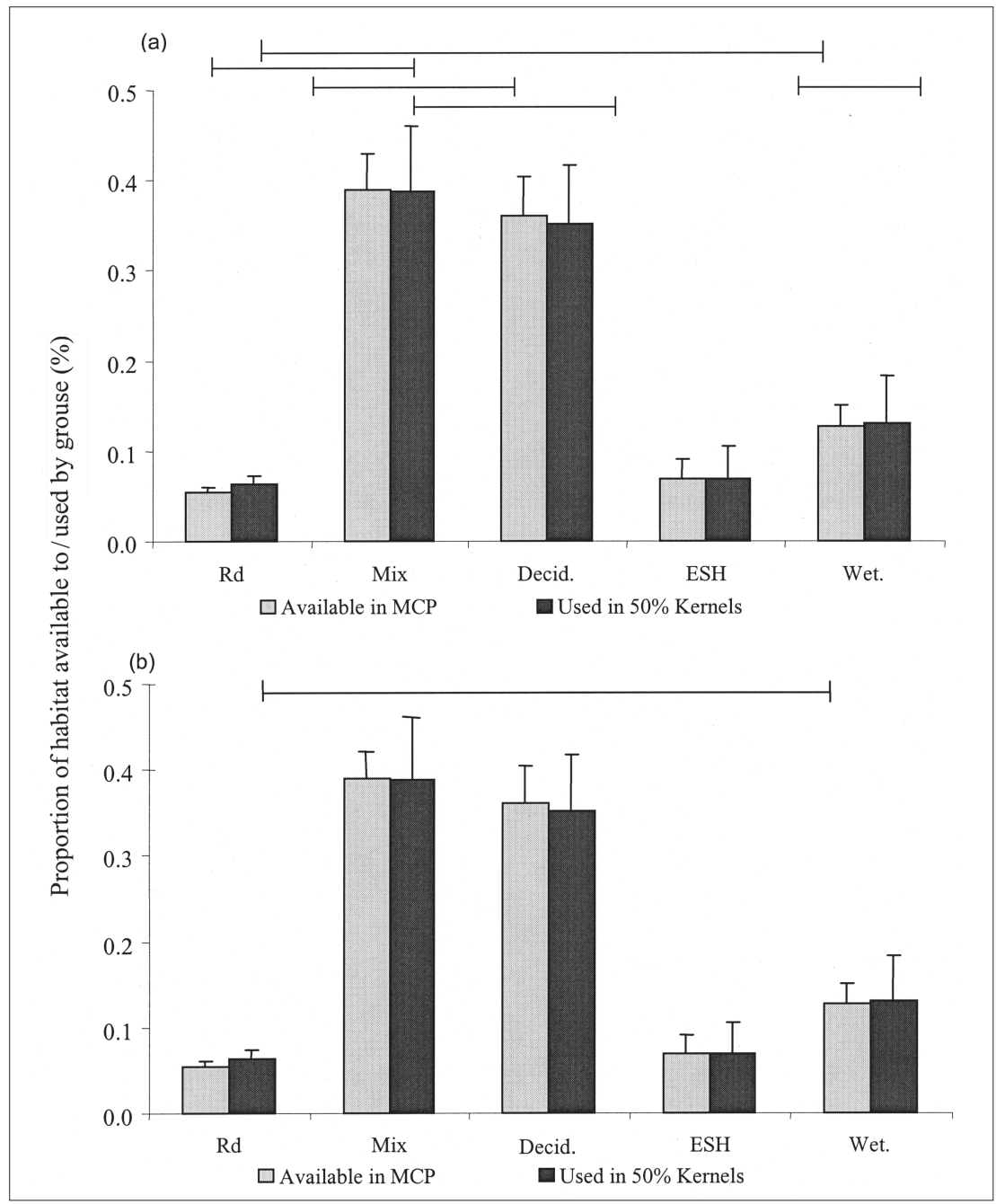

Figure 2. Habitat selection by Ruffed Grouse in Rhode Island during 1999-2002 at (a) the study-area scale $(n=26)$, and (b) the home-range scale $(n=18)$. Bars represent mean proportion $( \pm \mathrm{SE})$ of the total area for each habitat that was available or used. At the home-range scale, habitat availability was estimated using the minimum convex polygon (MCP) home range, and habitat use of grouse was estimated using the 50\%-kernel home range. At the study-area scale, habitat availability was estimated using the 95\%-kernel home range, and habitat use of grouse was estimated using the 95\%-kernel home range. Forest stand classes (see Table 1 for definitions of abbreviations) are ranked from left to right in decreasing order of selection. Lines with whiskers above stand classes indicate no significant difference (compositional analysis, $\mathrm{P} \geq 0.05$ ) in selection among forest stand classes. 
often less than several ha; Bump et al. 1947), whereas in poorer quality habitats, grouse may have to range widely to find sufficient cover and food (Hewitt and Kirkpatrick 1996). Furthermore, annual variability in hard mast crops, such as acorns, may also affect grouse home-range size. Whitaker (2003) reported grouse home ranges increased $2.5 x$ following poor fall mast crops. During our study, oak mast crops were moderate to low; however, they were high in 1998, the year before the study (Tefft, RI Department of Environmental Management, unpubl. data). Poor habitat quality and dispersed food resources in Rhode Island likely cause home-range size of grouse to be relatively large.

\section{Habitat selection by grouse}

Ruffed Grouse in Rhode Island primarily selected early successional habitats including mixed deciduous-conifer stands and roads, although the strength of this habitat selectivity depended on the spatial scale.

Preferred habitats. Grouse prefer early successional forests across their range (Bump et al. 1947), in part because they contain high tree densities that provide cover for grouse (Bump et al. 1947, Gullion 1990). Early successional habitats in our study site were rare $(<2 \%$ in area), but made up on average $>7 \%$ of the home range area of grouse. Most of this early successional habitat in Rhode Island was recently abandoned farmland. Maturation of these early successional forests may force grouse into other, less preferred habitat, unless management arrests or reverses the successional process.

The rarity of early successional habitats in our study area is representative of forests both in Rhode Island and the northeastern United States, which contains less early successional forest than in the central or southern United States (Trani et al. 2001). Today, forests in Rhode Island are mostly older second-growth forests created when many farms were abandoned during the early 1900s (Braun 1950, Butler and Wharton 2002). These forests lack the structural and compositional diversity historically provided by natural disturbances and forest management (Butler and Wharton 2002, Lorimer 2001).

Mixed-forest habitat dominated by scrub oak and pitch pine was common on our study site, and was selected by Ruffed Grouse. Scrub oak is a thicketforming shrub or small tree that may provide good cover and a source of acorns for Ruffed Grouse (Bump et al. 1947). However, Scott et al. (1998) found that grouse in Pennsylvania avoided mixed pitch pine-scrub oak habitats. They suggested that grouse avoided mixed habitat because they were exposed to predators in this habitat. Mixed forest habitat may be important to grouse in Rhode Island because it provides more food and cover than other available habitats, and because early successional habitat is rare.

The selection of roads by grouse at the study area scale is consistent with other studies of Ruffed Grouse habitat selection. For example, Schumacher (2002) found that grouse in North Carolina were located closer to roads than would be expected at random. Whitaker (2003) reported that selection of 
roads was positively related to selection of clearcuts in sites with oakhickory forests. Whitaker (2003) also found that female grouse used roads more frequently following poor fall mast crops, signifying the importance of roads as foraging areas when other food supplies become scarce. Berner and Geysel (1969) suggested that roads may serve the same purpose as small clearings for grouse. Herbaceous plants and grasses that grow along road edges may provide food during summer, especially during brood rearing. Hollifield and Dimmick (1995) reported high arthropod abundance along logging roads in the southern Appalachians. Roads also provide a place for dust-bathing, and can be used as a source for grit which may aid digestion (Bump et al. 1947).

Avoided habitats. Avoidance of developed areas by grouse was expected. Developed areas on our study site ranged from low- to high-density residential developments $(<1.2-19.5$ dwellings/ha; RIGIS). Forests in Rhode Island are becoming increasingly fragmented by human development and are often converted to housing subdivisions (Butler and Wharton 2002). On the Rhode Island study site, developed areas covered almost $5 \%$ of the land and were more abundant than early successional habitats.

Grouse in Rhode Island also avoided coniferous stands, which were mostly composed of white pine and Pinus resinosa Aiton (red pine). These stands of red pine in Rhode Island were planted in the 1960s following a large fire in the area in 1951. Today, these stands apparently represent poor quality habitat for Ruffed Grouse with little understory vegetation or food value. In Virginia, Fearer et al. (1999) also found that grouse avoided conifer stands. Similarly, grouse in Missouri avoided pine plantations in both spring-summer and fall-winter seasons (Thompson and Fritzell 1989). Bump et al. (1947) reported that nesting sites of grouse were unlikely to be near coniferous habitat, although conifer forests were the most used cover type at other times of the year in their study sites in New York.

\section{Management recommendations}

Ruffed Grouse populations in Rhode Island will likely continue to decrease without conservation and restoration of early successional habitats (see Dessecker and McAuley 2001, Hunter et al. 2001). The same holds true for other wildlife, such as American Woodcock (Dessecker and McAuley 2001), Chestnut-sided Warblers, Golden-winged Warblers, Cerulean Warblers (Askins 2000, Hunter et al. 2001), and New England cottontails (Litvaitis 1993), that also prefer early successional forests in New England. Therefore, if conservation of early successional communities is a management goal, then land managers in Rhode Island should focus on two main objectives. First, even-aged forest management should be used to provide early successional habitat. Even-aged silviculture is usually considered the best practice when managing for early successional species (Dessecker and McAuley 2001, Jones and Harper 2004, Thompson and Dessecker 1997, 
Thompson and DeGraaf 2001). Second, further incursions of non-forest land uses should be avoided so that remaining blocks of contiguous forest can be retained. Developments, especially housing subdivisions, reduce both the habitat available to wildlife and the opportunities to harvest timber (Butler and Wharton 2002, Trani et al. 2001).

Management of early successional habitats in the Northeast is complicated by the preponderance of privately owned land in this region (Trani et al. 2001). Alternative silvicultural methods (e.g., selective harvesting) are becoming increasingly popular because of the public perception of negative aesthetic or ecological effects from even-aged management (Gobster 2001, Jones and Harper 2004, Trani et al. 2001). On private land, conservation easements can be used to prevent development and offer conservation opportunities to private landowners (Litvaitis 2001). Technical assistance and funding can be provided to qualified individuals interested in wildlife conservation if they apply to programs such as the Conservation Reserve Program offered by the USDA's Farm Service Agency. Brooks and Birch (1988) concluded that although private forest landowners in New England were not motivated to manage forests solely for economic gain, actions that encourage landowners to use silviculture to improve wildlife habitat could have positive results.

\section{Acknowledgments}

Primary funding and personnel were provided by Rhode Island Division of Fish and Wildlife (W-23-R), the University of Rhode Island Department of Natural Resources Science, the Rhode Island Agricultural Experiment Station, the Rhode Island Champlin Foundations, and the Richard King Mellon Foundation. Partial funding and additional logistical support for the project was provided by the Ruffed Grouse Society and the Meadwestvaco Corporation. We owe the following individuals a great deal of thanks for technical support and for exchanging ideas with us: Gary Norman, Mark Banker, Dan Dessecker, Pat Keyser, Dean Stauffer, Darroch Whitaker, Pat Devers, Tom Allen, Bill Igo, Scott Klopfer, and Jeff Hollister. We are deeply indebted to the following people for their help collecting the field data, without which there would be nothing to report: Valerie Mitchell, Michael Huguenin, Michael Pouliot, Adam Gebauer, Peter Keller, Bill Igo, and Tom Devers. This research is contribution number 5031 for the Rhode Island Experiment Station.

\section{Literature Cited}

Aebischer, N.J., P.A. Robertson, and R.E. Kenward. 1993. Compositional analysis of habitat use from animal radio-tracking data. Ecology 74:1313-1325.

Askins, R.A. 2000. Restoring North America's Birds: Lessons from Landscape Ecology. Yale University, New Haven, CT. 332 pp.

Berner, A., and L.W. Gysel. 1969. Habitat analysis and management considerations for Ruffed Grouse for a multiple use area in Michigan. Journal of Wildlife Management 33:769-778. 
Boyd, R.A. 1990. Population density and habitat utilization of Ruffed Grouse in the southern Appalachians. M.Sc. Thesis, University of Tennessee, Knoxville, TN.

Braun, E.L. 1950. Deciduous Forests of Eastern North America. Blakiston Company, Philadelphia, PA. 596 pp.

Brooks, R.T., and T.W. Birch. 1988. Changes in New England forests and forest owners: Implications for wildlife habitat resources and management. Transactions of the North American Wildlife and Natural Resources Conference 53:78-87.

Bump, G., R.W. Darrow, F.C. Edminster, and W.F. Crissy. 1947. The Ruffed Grouse: Life History, Propagation, Management. New York Conservation Department, Buffalo, NY. 915 pp.

Burt, W.H. 1943. Territoriality and home range concepts as applied to mammals. Journal of Mammalogy 24:346-352.

Butler, B.J., and E.H. Wharton. 2002. The Forests of Rhode Island. Northeastern Research Station Report NE-INF-155-02. US Department of Agriculture, Newtown Square, PA.

Davis, J.A. 1969. Aging and sexing criteria for Ohio Ruffed Grouse. Journal of Wildlife Management 33:628-636.

Dessecker, D.R., and D.G. McAuley. 2001. Importance of early successional habitat to Ruffed Grouse and American Woodcock. Wildlife Society Bulletin 29:456-465.

Environmental Systems Research Institute (ESRI). 1994. Arc Commands: ARC/ INFO. Version 7. Redlands, CA.

Fearer, T.M., D.F. Stauffer, and R.L. Kirkpatrick. 1999. Relationship of Ruffed Grouse home-range size and movement to landscape characteristics in southwestern Virginia. Report to the Virginia Department of Game and Inland Fisheries, Blacksburg, VA.

Fenneman, N.M. 1938. Physiography of the Eastern United States. McGraw-Hill, New York, NY. 714 pp.

Gobster, P.H. 2001. Human dimensions of early successional landscapes in the eastern United States. Wildlife Society Bulletin 29:474-482.

Godfrey, G.A. 1975. Home-range characteristics of Ruffed Grouse broods in Minnesota. Journal of Wildlife Management 39:287-298.

Gullion, G.W. 1965. Improvements in methods for trapping and marking Ruffed Grouse. Journal of Wildlife Management 29:109-116.

Gullion, G.W. 1990. Management of aspen for Ruffed Grouse and other wildlife: An update. Pp. 133-143, In R.D. Adams (Ed.). Aspen Symposium 1989 proceedings. Forest Service General Technical Report NC-140. US Department of Agriculture, Duluth, MN. 338 pp.

Hewitt, G.D., and R.L. Kirkpatrick. 1996. Forage intake rates of Ruffed Grouse and potential effects on grouse density. Canadian Journal of Zoology 74:2016-2024.

Hollifield, B.K., and R.W. Dimmick. 1995. Arthropod abundance relative to forest management practices benefiting Ruffed Grouse in the southern Appalachians. Wildlife Society Bulletin 23:756-764.

Hooge, P.N., W. Eichenlaub, and E. Solomon. 1999. The Animal Movement Program. Version 2.0: USGS, Alaska Biological Science Center, Anchorage, AK.

Hunter, W.C., D.A. Buehler, R.A. Canterbury, J.L. Confer, and P.B. Hamel. 2001. Conservation of disturbance-dependent birds in eastern North America. Wildlife Society Bulletin 29:440-455. 
Jennrich, R.I., and F.B. Turner. 1969. Measurement of non-circular home range. Journal of Theoretical Biology 22:227-237.

Johnson, D.H. 1980. The comparison of usage and availability measurements for evaluating resource preference. Ecology 61:65-71.

Jones, B.C., and C.A. Harper. 2004. Habitat management. Pp. 47-54, In G.W. Norman, et al. (Ed.). Ruffed Grouse Ecology and Management in the Appalachian Region. Final Project Report of the Appalachian Cooperative Grouse Research Project, Blacksburg, VA.

Litvaitis, J.A. 1993. Response of early successional vertebrates to historic changes in landuse. Conservation Biology 7:866-873.

Litvaitis, J.A. 2001. Importance of early successional habitats to mammals in eastern forests. Wildlife Society Bulletin 29:466-473.

Litvaitis, J.A., J.A. Sherburne, and J.A. Bissonette. 1986. Bobcat habitat use and home-range size in relation to prey density. Journal of Wildlife Management 50:110-117.

Lorimer, C.G. 2001. Historical and ecological roles of disturbance in eastern North American forests: 9000 years of change. Wildlife Society Bulletin 29:425-239.

Maxson, S.J. 1974. Activity, home range, and habitat usage of female Ruffed Grouse during the egg-laying, incubation, and early brood periods as determined by radiotelemetry. M.Sc. Thesis. University of Minnesota, St. Paul, MN.

McNab, B.K. 1963. Bioenergetics and the determination of home-range size. The American Naturalist 97:133-140.

Mohr, C.O. 1947. Table of equivalent populations of North American small mammals. American Midland Naturalist 37:223-249.

Neu, C.W., C.R. Byers, and J.M. Peek. 1974. A technique for analysis of utilizationavailability data. Journal of Wildlife Management 38:541-545.

Ott, P., and F. Hovey. 2002. Program Bycomp.sas. Version 1.0.

Porter, W.F., and K.E. Church. 1987. Effects of environmental pattern on habitat preference analysis. Journal of Wildlife Management 51:681-685.

SAS Institute. 1989. SAS/STAT(R) user's guide. SAS Institute Inc., Cary, NC.

Schumacher, C.L. 2002. Ruffed Grouse habitat use in western North Carolina. M.Sc. Thesis. University of Tennessee, Knoxville, TN.

Scott, J.G., M.J. Lovallo, G.L. Storm, and W.M. Tzilkowski. 1998. Summer habitat use by Ruffed Grouse with broods in central Pennsylvania. Journal of Field Ornithology 69:474-485.

Seaman, D.E., and R.A. Powell. 1996. An evaluation of the accuracy of kerneldensity estimators for home-range analysis. Ecology 77:2075-2085.

Seaman, D.E., J.J. Millspaugh, B.J. Kernohan, G.C. Brundige, K.J. Raedeke, and R.A. Gitzen. 1999. Effects of sample size on kernel home-range estimates. Journal of Wildlife Management 63:739-747.

Statistical Package for Social Sciences (SPSS). 1999. SPSS Base 10.0 Applications Guide. SPSS, Chicago, IL.

Tefft, B.C. 1999. Population dynamics of the Ruffed Grouse in Rhode Island. Job performance report of Rhode Island Federal Aid in Wildlife Restoration Grant W-23-R, Job 1-12.Rhode Island Department of Environmental Management, Division of fish and Wildlife, Kingston, RI.

Thompson III, F.R., and R.M. DeGraaf. 2001. Conservation approaches for woody, early successional communities in the eastern United States. Wildlife Society Bulletin 29:483-494. 
Thompson III, F.R., and D.R. Dessecker. 1997. Management of early successional communities in central hardwood forests. Report NC-195. US Department of Agriculture Forest Service, North Central Forest Experiment Station, St. Paul, MN.

Thompson III, F.R., and E.K. Fritzell. 1989. Habitat use, home range, and survival of territorial male Ruffed Grouse. Journal of Wildlife Management 53:15-21.

Trani, M.K., R.T. Brooks, T.L. Schmidt, V.A. Rudis, and C.M. Gabbard. 2001. Patterns and trends of early successional forests in the eastern United States. Wildlife Society Bulletin 29:413-424.

Whitaker, D.M. 2003. Ruffed Grouse (Bonassa umbellus) habitat ecology in the central and southern Appalachians. Ph.D. Dissertation. Virginia Tech University, Blacksburg, VA.

Worton, B.J. 1989. Kernel methods for estimating the utilization distribution in home-range studies. Ecology 70:164-168. 